\title{
Endüstri 4.0 Bağlamında Türkiye’nin Yerine İlişkin Güncel ve Gelecek Eksenli Bir Analiz ${ }^{1}$ With Respect to Industy 4.0 an Analysis on Turkey's Current and Future State
}

Zeki YÜKSEKBİLGILI $\dot{I}^{2}$

Gözde Zeynep ÇEVIK

Öz:

Son yıllarda üretim sektöründe yaşanan büyük sanayi gelişimleri ve devrimleri üzerine devletler rekabet edebilmek adına kendilerini bu hızlı değişim furyasına uydurmak mecburiyetinde hissetmiş ve bu bağlamda bazı stratejiler geliştirmişlerdir. Endüstri 4.0 ise 2011 yılında gündeme gelmeye başlamış olan bu stratejilere verilmiş olan isimdir. Makineleşme, internet ve otomasyon sistemlerinde bir üst seviyeyi işaret eden bu kavramın ortaya çıkışının temelleri üreticilerin her zaman olduğu gibi yüksek verimlilik ve katma değer artışı arayışı ile atılmıştır denilebilir. Bütün büyük ekonomilerin ve gelişmekte olan ekonomilerin başarılı şekilde bu stratejilere uyum sağlayabilmesi onların gelecekte uluslararası konjonktürde yer alacakları konum açısından önem taşımaktadır. Bu çalışmada da Endüstri 4.0'ın günümüze getirdikleri ve gelecekte getirmesi beklenen katma değerlerin analiz edilebilmesi adına dünyada ve Türkiye'de endüstriyel devrim çağları incelenmiştir. Bu bağlamda endüstri 4.0 konusunda öncü 6 firmanın üst düzey yöneticileri ile mülakat yapılmıştır. Yapılan mülakat sorularına verilen cevaplardaki ortak yorumlar anahtar kelime analizine tabi tutulmuş ve yorumlanmıştır. Araştırma bulguları ülkemizde Endüstri 4.0'ın farkındalığının oluşmuş durumda olduğunu ve gerek şirketler, gerekse devlet kurumlarında, Türkiye'nin yol haritasının oluşturulduğunu ve çalışmalara başlanıldığını göstermektedir.

Anahtar Kelimeler: Sanayi, endüstri, rekabet, ekonomi, devrim, pazarlama.

JEL Kodu: R59, R10, Q49

\begin{abstract}
:
Major improvements and reforms in production sector which have been taking place at recent years, forced governments to adapt themselves to these fast changing developments in order to be able to compete with other international economical actors. For this purpose, they started to develop some new strategies. Industry 4.0 is the name of one of these strategies which started to take place in 2011. One step forward on mechanization in production processes, internet and automation are the concepts which Industry 4.0 refers to. It may be said that these developments and related strategies are coming from the need of high productivity and search for new added values. Whole major economies and developing economies would have a powerful status in international conjuncture if only they can manage to integrate their processes to the fast changing world. In this study, in order to analyze the current and also future returns and profits of Industry 4.0; industrial periods and reform ages will be examined in whole world. The outcomes of these examinations will be compared to Turkey's economy and this study will assess the current situation of our country in the context of Industry 4.0. In this regards, structured interviews were conducted with senior management positions that are pioneers of Industry 4.0 in Turkey. A qualitative data analysis was made based on keyword analysis. The results show that both public and private sector is aware of Industry 4.0 and have settled their roadmaps. Keywords: Industry, industrial, competition, economy, reform, marketing.
\end{abstract}

JEL Codes: R59, R10, Q49

\footnotetext{
${ }^{1}$ Bu çalışma 2018 yılında NIŞANTAŞI ÜNIVERSITESİ, Sosyal Bilimler Enstitüsü, İşletme Yönetimi Bölümü’ne yüksek lisans tezi olarak sunulan ve kabul edilen tez çalışmasindan türetilmiştir.

${ }^{2}$ Dr. Öğr. Üy., Zeki YÜKSEKBiLGiLi, Nişantaşı Üniversitesi, yuksekbilgili@gmail.com

${ }^{3}$ Gözde Zeynep ÇEViK, Yüksek Lisans Öğrencisi
} 


\section{LITERATÜR \\ 1.1. Kronolojik Olarak Endüstriyel Devrimler}

Sanayi kelimesi, Latincedeki “industria” kelimesinden dilimize uyarlanmış olup Fransızcada da "industrie” biçiminde kullanılmaktadır. Türkçede zaman zaman Fransızca okunuşu ile "endüstri” olarak kullanılmaktadır. Ekonomik kapsamda ise sanayi; maden kaynakları ile çeşitli enerji kaynaklarının kullanılarak farklı hammaddelerin birer ürün haline getirilmesini hedefleyen finansal faaliyetler ve bu faaliyetlerde kullanılan araçların tamamı olarak kullanılmaktadır (Özüdoğru, 2010: 2).

Tarihteki sanayi faaliyeti kapsamında değerlendirilebilecek ilk etkinlikler insanlık tarihi kadar eskidir, çünkü insanlar var olduklarından beri hayatta kalabilmek için çeşitli mücadele vermek mecburiyetinde kalmıştır. Vahşi hayvanlardan, zorlu doğa koşullarından korunabilmek ve karınlarını doyurabilmek için doğada buldukları kemik, bitki vb. malzemeler ile çeşitli aletler üretmişlerdir. Sanayi devrimlerinin her biri insanlık tarihinde önemli yerlere sahiptir. Bu önemin sebebi ise sanayi devrimlerinin endüstri ve üretim sektörlerinin ötesinde insanların ve dolayısıyla toplumların yaşam tarzlarına hatta toplumsal edebiyata dahi etki etmesi, mevcut olanı değiştirmesidir. İlk olarak 18. yy.da İngiltere'de yaşanan gelişmeler ile ortaya çıkmaya başlayan ilk sanayi devrimi, yeni bir çağın başlangıcını temsil etmiștir. Teknoloji ile paralel olarak gelişim gösteren endüstri, insan ihtiyaçları ve ticaret dinamiklerinin değişimi yıllar içerisinde benzer büyük çaplı değişikliklerin tekrarlanmasına yol açmıştır. Yaşanan bu gelişmeler kronolojik olarak aşă̆ıdaki gibidir:

\subsubsection{Birinci Sanayi Devrimi}

Endüstri Devrimi, 1760-1840 tarihleri arasında İngiltere'de, James Watt adlı bir İskoç'un buhar makinesini bulması ve bunu üretim süreçlerine dahil etmesi ise ortaya çıkan bir süreçtir (Üskent, 2006: 2). Sanayi Devrimi kısaca, kas gücünün egemen olduğu üretim şeklinden, makine gücünün egemen olduğu üretim şekline geçiş olarak tanımlanabilmektedir (Özdemir, 2014).

Sanayi Devrimi'nin başlaması için uygun olan bu koşullar arasında başı çeken Avrupa'nın zenginleşmesidir denilebilir. 16. ve 17. yüzyıllarda çok yaygın bir şekilde uygulanan sömürgecilik Avrupa ülkelerini finanse etmiş ve gelişmelerini sağlamıştır. Hem İspanyolların Orta Amerika kolonilerinin altınlarını sömürmeleri hem de onların gemilerinin İngiliz korsanları tarafından sömürülmesi Avrupa'ya oldukça fazla altın kazandırmıştır (http://www.tarihiolaylar.com/tarihi-olaylar/sanayi-devrimi-1107). Bölgede yaşanan bu zenginleşme kapitalist sistemi de desteklemiş, burjuva sınıfının temellerini oluşturmuş ve tüketim taleplerini arttırarak yeni yatırım alanı arayışlarını tetiklemiştir. Bütün bu gelişmeler de Birinci Sanayi Devrimi’ni doğurmuştur. En son olarak da James Watt'ın 1698'de üretilmeye başlanan Newcomen buhar makinesini tamir etme firsatı bulması ile onu geliştirip yeni ve daha verimli çalışan buhar makinesini icat etmesi sonucu olaylar zinciri hızlanmış, endüstri başka bir boyuta taşınmış ve sonuçları hayatın pek çok farklı alanı üzerinde de etkili olmuştur (http://www.bbc.co.uk/history/historic_figures/watt_james.shtm).

\subsection{2. İkinci Sanayi Devrimi}

İkinci Sanayi Devrimi, ilk aşama olan ilk sanayi devriminin bittiği 1870 yılından itibaren Birinci Dünya Savaşı'nın başladığı dönem olan 1914 yılına kadar geçen süreçte meydana gelen teknolojik gelişmeler ile bunların getirdiği ekonomik ve sosyal değişiklileri ifade etmektedir (http://blog.kavrakoglu.com/tag/ikinci-sanayi-devrimi/). Endüstriyel devrimin ilk aşamasının sonucunda gelişen demiryolları ile nakliye ve bu sayede hızla büyüyüp ivme kazanan ticaret, demiryollarının dayanıklı çelik üretimine olan arzını doğurmuş bu da sanayi devriminin yeni aşaması için itici güç rolünü oynamıştır. İkinci Sanayi Devrimi'nin belirleyici faktörleri ise petrol ve benzeri hammaddelerin ekonomi içerisinde sahip olduğu önem, elektriğin kullanılmaya başlanması, petrol ile çalışan içten yanmalı motorlar ve dolayısıyla otomotiv sektörünün gelişmesi olmuştur. Ayrıca bu dönemde telgraf ve radyo bağlantılarının geliştirilmesi sayesinde oluşan yeni imkânlar ile borsa ve hisse senedi piyasaları oluşmuştur (http://ushistoryscene.com/article/second-industrial-revolution). Bu dönemde işçilerin durumuna bakıldiğında ise sendikalaşmanın daha fazla kabul gördüğü ve bilgi toplumunun önem kazanmış olmasına bağlı olarak beyaz yakalı çalışanların sayısının fazlalaştığ 1 gözlemlenebilir.

Çoğu görüşe göre 2. Sanayi Devrimi'nin olumsuz sonuçları olmuştur. Teknolojik gelişmelerin getirdiği fazla karbon ve doğal kaynak tüketimi dünyayı, çevreyi negatif yönde etkilemiş ve küresel ısınma gibi bugünkü pek çok çevre sorununun ortaya çıkmasına zemin hazırlamıştır.

\subsection{3. Üçüncü Sanayi Devrimi}


Birinci Endüstri Devrimi’nde su ve buhar gücü; İkinci Endüstri devriminde ise petrol ve elektrik ana enerji kaynaklarıdır. Üçüncü Endüstri Devrimi’nde ise, güneş enerjisi, rüzgar enerjisi gibi yenilenebilir enerji kaynakları önem kazanmıştır. Yarı iletkenlerin, ana bilgisayarların, kişisel bilgisayarların ve internetin çevresinde geliştiği için çoğunlukla dijital devrim ya da bilgisayar devrimi olarak adlandırılmıştır. Sanayi devrimi genel olarak medeniyete doğru atılmış adımlar bütünü gibi görünse de bazı getirileri olumsuz sonuçlara yol açmıştır. Birinci ve ikinci sanayi devrimlerinden sonra doğal kaynaklar ve hammaddelerin tüketimi hızla arttığından dünyadaki kaynaklar da aynı hızda azalmaya ve risk altına girmeye başlamıştır. Bu sebeple de doğal hayat ve çevre negatif yönde etkilenmiş ve kaynaklar sürdürülebilirliğini yitirmeye başlamıştır. Sürdürülebilirliğin risk altına girdiği fark edildiğinde ise teknoloji çevre dostu olmaya yöneltilmiş ve yenilenebilir enerji kaynaklarının kullanılabilmesi için çalışmalara başlanmıştır. Bu gelişmeler de Üçüncü Sanayi Devrimi’ni getirmiştir. Ekonomik bir devriminin oluşması için yeni bir enerji kaynağı ile yeni bir iletişim teknolojisinin ortaya çıkması gerekmektedir. Bu iki olgunun bir araya geldiği koşullarda ise yaşam başka bir boyuta geçecektir. Örneğin Birinci Sanayi Devrimi kömür ile matbaanın aynı anda gelişip birleşmesi ile patlayıp yayılmıştır. 2. Sanayi Devrimi ise petrol ve yeni iletişim gereçlerinin bir araya gelmesinden doğmuştur. 3 . Sanayi Devrimi de yenilenebilir enerji ile internetin ortaklığından ortaya çıkmıştır (Rifkin, 2014: 57-60). Aslında İkinci Sanayi Devrimi olup bittikten sonra 1970'lerden itibaren yaşanan pek çok teknolojik gelişmeye ve bu olaylar zincirine Üçüncü Sanayi Devrimi Adını kullanan ve yaygınlaşmasını sağlayan aynı isimli kitabı ile Jeremy Rifkin olmuştur. Ayrıca The Economist dergisinin de bu konu üzerinde ses getiren bir makale yayınlaması 3. Sanayi Devrimi kavramının akıllarda iyice yer etmesini sağlamıştır. Economist'in makalesinde bu devrim ile yeni dönemde üretim dijitalleşmektedir. Çok fazla insanın üretimde yer aldığı ve verimliliği düşük, kendisi çok büyük olan fabrikalar bu yeni dönemde aynı şekilde faaliyetlerine devam edemeyeceklerdir. 3D yazıcılar, kullanımı kolay robotlar gibi yeni aletler ve teknolojik gelişmeler sayesinde çok daha az insanın üretim süreçlerinde yer aldığı ancak verimliliğin çok daha yüksek olduğu bir endüstri ortamı oluşmaktadır. Bu koşulların, üretimin pahalı olması sebebi ile az gelişmiş ülkelere yönlendirilen üretim bağlamında, zengin ülkelere yeniden iş olanakları doğurabileceği de bu haberde öne sürülmüştür (http://www.economist.com/node/21552901). Endüstrideki bu 3. devrim çok daha farkl1 ve yeni çok yeni koşullar yaratmıştır. Yeni buluşlara ait aletler eskilerinden daha hafif, daha dayanıklı hale gelerek pek çok farklı üretim dalında kullanılır hale gelmiştir. İnternet ise tasarım alanında farklı dizayn yapanların iş birlikleri kurmasına ortam hazırlamaktadir.

\subsubsection{Dördüncü Sanayi Devrimi}

Sanayi ya da Endüstri 4.0 bugün içerisinde olduğumuz bir süreci ifade etmektedir. Dolayısıyla henüz tamamlanmış bir dönem değildir ve geleceğine dair teoriler üzerinde durulmaktadır. Endüstri 4.0 genel itibariyle; robotların üretimi devralması, üç boyutlu yazıcılar ile üretim, yapay zekanın gelişmesi, büyük veri çalışmaları ve daha birçok yeniliklerle incelenebilir (https:/www.muhendisbeyinler.net/4-sanayi-devrimi-nedir/). Almanya, Japonya ve ABD tarafindan destek görmüştür.

Sanayi 4.0'ın (Industry 4.0) kuramsal başlangıcı için Kagermann'ın 2011 tarihli makalesi esas alınmaktadır. Kagerman (2011) 4. Sanayi devriminin sadece otomasyondaki gelişimi değil, aynı zamanda akıllı gözlem ve karar alma süreçlerini de içermekte olduğunu ifade etmektedir (Alçın, 2016: 21). "Nesnelerin İnterneti”, "Her Şeyin İnterneti" veya "Endüstriyel İnternet" isimleri ile de bilinen bu değişiklikleri ilk üç sanayi devriminden ayırmaya yarayacak karakteristikleri şu şekilde sıralanabilir:

- Siber fiziksel sistemler (CPS): Bu sistemler sensörler aracılığı ile reel fiziksel dünyayı sanal bilgi işlem dünya ile bağlamaktadırlar. Geniş bir iletişim ağı oluşturan ve bu sayede reel ile sanal dünyalar arasındaki sınırları ortadan kaldırmayı sağlayan sistemler Endüstri 4.0'ın da en temel itici güçlerinden bir konumundadır (http://www.endustri40.com/siber-fiziksel-sistemler/). Siber fiziksel sistemler sayesinde gelecekteki tesisler yeni oluşturulmuş koşullar ve arayüzlere sahip olacak, bu arayüzlerin eş zamanlı olarak kontrol edilebilmesi, üretim süreçlerindeki donanımların en son yenilikleri ile güncellenmesi konularında daha esnek olunabilecektir. Bu sayede de ilgili bütün değişikliklerin üretim süreçlerine uyarlanması daha az zaman alacak ve potansiyel olumsuzluklar ile aksaklıkların minimum seviyeye çekilebilmesi mümkün olacaktır. Bütün bunlar da doğal olarak verimlilik seviyesini daha yukarılara taşıyacaktır.

- $\quad$ Büyük Veri: Sanayi 4.0 ile şekillenen geleceğin üretim tesislerinde işlenip kaydedilmesi gereken çok daha fazla veri hareketi olacağından inovatif veri sistemlerinin kullanılması önem taşımaktadır. "İnternette, çeşitli sosyal medya sitelerinde yapılan paylaşımlar, bloglar, fotoğraf, video gibi değişik kaynaklardan akan tüm verinin, anlamlı ve işlenebilir biçime dönüştürülmüş haline denir. Büyük veri; internet istatistikleri, sosyal medya yayınları, bloglar ve benzeri sensörlerden gelen bilgiler gibi çok büyük sayıda veriden oluşmaktadır (https://tr.wikipedia.org/wiki/B\%C3\%BCy\%C3\%BCk_veri). Bu veriler, doğru şekilde analiz edilip yorumlanabilirse işletmelerin; doğru şekilde önemli stratejik kararlar almalarını, riski en az seviyede tutup daha iyi yönetebilmelerini bu sayede yüksek verimlilik ile çalışabilmelerini sağlamaktadır (http://www.mckinsey.com/businessfunctions/operations/our-insights/how-big-data-can-improve-manufacturing).

- Dijital Bilgi Alışverişi: Sanayi 4.0'ın temel felsefelerinden biri sanal ve gerçek dünyanın birbirine bağlanmasıdır. İçerikler, donanımlar, bileşenler, sistemler ve insanlar arasında internet aracılığı ile sağlanan kesintisiz bilgi alışverişi sayesinde nihai ürünler, makineler, içerikler ve üretimdeki her adımın dijital ayak izleri olacaktır. Bu 
sayede de üretimin daha hızlı, esnek ve düşük risk yüksek verimlilik ile yapılabileceği düşünülmektedir. Buna göre akıllı fabrikalar, güncel koşullara durumlara otomatik olarak uyum sağlayacak, sipariş taleplerine göre üretim planlamalarını organize edecektir (Taghizadeh, 2015).

- Akıllı Robotlar: İnsan kaynaklı hataları sonlandırması beklenen robotlar, üretimde yaygın şekilde kullanılmaktadır. Dolayısıyla robot teknolojileri, Dördüncü Sanayi Devrimi'nin, yani Endüstri 4.0'ın etkisini artırtmak açısından gelecek vaat etmektedir. Örneğin, akıllı fabrikalardaki robotlar birbiri ile iletişim halinde, iş bölümü yaparak, değişiklikleri analiz edip tepki vererek üretimi yönetebilir hale gelecektir. Bu robotlar klasik üretim bandında hareket eden malzemeleri sensör teknolojileri sayesinde ayırt ederek, hangi aşama ve işlemler tabi tutulması gerektiğini bilmektedir. Bu sayede her bir farklı ürünün tek bir üretim bandında hatasız şekilde işlenmesi sağlanabilmektedir.

- $\quad$ Dijital Sanayileşme: Sanayi 4.0 ile üretim süreçlerinin tamamı, seri üretimden önce, ilk etapta planlanıp sanal bir üretim programı planı aracılığıyla sağlanacaktır. Tüm adımlar, öncelikle sanal olarak doğrulanacak sonrasında fiziksel üretim tamamlanacaktır.

\subsection{Kavramsal Olarak Endüstri 4.0}

İlk üç sanayi devrimi süresi içerisinde yaşanan en önemli gelişmelerden biri de Dünya kaynaklarının çok hızlı tükenmesi ve sürdürülebilirlik kavramının öncelik kazanması olmuştur. Almanya'da yaşanan endüstriyel değişim sürecine bakarak bu devrime neden Endüstri 4.0 adı verildiği anlaşılabilmektedir. Almanya Eğitim ve Araştırma Bakanlığı, mevcut konjonktürde ve öngörülebilen gelecekte ülkenin kalkınmasını güçlendirmeye yönelik yaptığı çalışmalar sonucu, 2011 yılında 10 ana projeyi duyurmuştur. 'Gelecek Projesi' adındaki bu projeler, 'Yüksek Teknoloji Stratejisi 2020'nin Gelecek Projeleri’ adı altında yayınlanmıştır Bu projeler, günlük yaşamın kavramlarına odaklanmıştır: Karbon emisyonlarının azaltılması, çevre dostu ve akıllı şehirler kurulması, alternatif yakıtların kullanılması, akıllı şebekelere geçiş yapılmasıdır. Projelerden biri de, Almanca ‘Industrie 4.0' olarak isimlendirilmiş ve ilk olarak 2011 Hannover Fuarı'nda açıklanmıştır. Teknolojileri, akımları, bilgisayar programlarını, bilgi teknolojileri çözümlerini 1.0, 2.0 şeklinde isimlendirildiği bir dönemde, 'yeni’ endüstrinin de bu şekilde adlandırılması normal karşılanmıştır. Alman hükümeti, projeye ilk aşamada 200 milyon Euro yatırım yapmıştır. Sonrasında, Federal Almanya Ulusal Bilim ve Araştırma Akademisi önderliğinde ''Endüstri 4.0 Strateji Belgesi' hazırlanmış ve 2013'te yine Hannover Fuarı'nda duyurulmuştur.

Endüstri 4.0'ın temelinde; endüstriyel üretimle ilgili bütün kalemlerin birbiriyle haberleşmesi, bütün verilere gerçek zamanlı olarak erişilmesi ve bu veriler sayesinde optimal katma değer sağlanması bulunmaktadır. Bu kavramın temel esasları şu şekilde belirtilmiştir: Endüstriyel internet, entegre edilebilen analizler, dijitalleşen süreçler, inovatif iş modelleri, bütün üretim ve değer zinciri çerçevesinde yatay işbirlikleri (Akeson, 2016: 2). Zaman ilerledikçe Endüstri 4.0 olgusu, iş dünyasının ve akademik çevrelerin de katkılarıyla Almanya olarak kalmayıp yeni bir endüstriyel sistem kurmayı tasarlayan bütün ülkelerin ilgi alanı haline gelmiştir.

\subsubsection{Teknolojik İlerlemeler}

Endüstri 4.0, dijital değişim faktörleri ile gelecekte söz sahibi olacak olan akıllı üretim ekonomisini ortaya çıkartmaktadır. Uluslararası rekabette söz sahibi olmayı hedefleyen işletmeler kendilerini bu yeni düzende vazgeçilmez roller oynayacak olan akıllı robotlar, pazarlama ve yönetim aşamalarında kullanılabilecek yapay zeka sistemleri, Ar-Ge departmanları ve bütün bunların fiziksel dünya ile arasındaki bilgi akışını yürütecek internet temelli sistemler ile bu sistemlerin bir arada uyumlu şekilde işlemesini sağlayacak çalışan ekipler ile desteklemeleri ve geliştirmeleri gerekmektedir. Teknoloji alanındaki gelişmeler başlangıcından beri sanayi devrimlerinin temel itici gücü olmuşlardır. 18. yüzyılda buhar gücüyle çalışan makineler üretim süreçlerine dahil edilmeye başlanmış, 20. Yüzyılda başında elektrik enerjisi ile seri üretim doğmuş ve verimlilik artmıştır. 1970’lerden sonra ise bilgi teknolojilerinin endüstride kullanımı ile otomasyon sistemleri yayılmaya başlamıştır. Dört temel akım iş hayatında oldukça büyük değişikliklere yol açarak bu devrimin de temelini atmıştır. Bu akımlar şu şekilde açıklanabilir:

- Bölgesel akımlar - Ülkeler arasındaki sosyal etkileşim ve ticarette artış

- Ekonomik akımlar - Yükselen yeni güçlü ekonomiler ve finansal kaynak akışları ile artan küreselleşme

- Teknolojik akımlar - Artan bağlanabilirlik ve platform teknolojilerinin gelişmesi

- Meta akımlar - Giderek kıtlaşan kaynaklar, çevre ve güvenlikle ilgili artan kayglar"(http://www.otomasyondergisi.com.tr/arsiv/yazi/97-turkiyenin-kuresel-rekabetciligi-icin-birgereklilik-olarak-sanayi-40).

Bu 4 oluşum sensörlerin, bilgi teknolojilerinin ve üretim gereçlerinin gittikçe birbirine bağlandığı işleyişlerin temelini oluşturarak yeni değer zincirleri ortaya çıkartmışlardır. Siber-fiziksel sistemleri ismi ile bilinen bu sistemler, internet entegrasyonu sayesinde birbirleri arasında bilgi ve veri alışverişi sağlayarak olası hataları öngörebilmek ve güncellenen koşullara hızlı adapte olabilmek amacı ile verileri analiz etmektedirler.

Sanayi 4.0 kapsamındaki teknolojik ilerlemeler 9 başlık altında toplanabilir. Bunlar;

- Büyük veri analiz,

- Zenginleştirilmiş gerçeklik,

- Eklemeli üretim, 
- Bulut,

- Siber güvenlik,

- Nesnelerin interneti,

- Yatay / dikey yazılım entegrasyonu,

- Simülasyon,

- Ak1lli robotlar (http://www.gazeteekonomi.com/ekonomi/sanayi-40-konferansinda-engelse-gondermeh153237.html).

\subsubsection{Siber Fiziksel Sistemler}

Günümüzde birbirine bağlı olmayan sistemleri kullanan hala çok fazla organizasyon olmasına karşılık gün geçtikçe bağlanabilirlik artmakta ve endüstride önemli bir yer tutmaya başlamıştır. Bugün artık fiziki dünya ile sanal dünyayı birbirinden ayrı şekilde düşünmek çok mümkün olmamaktadır. Sanal dünya gerçek dünya üzerine kurulmuşken, fiziksel hayatın sınırları sanal dünya tarafından genişletilmektedir. İşte bu iki dünyanın arasındaki bağlantıyı ve bilgi alışverişini sağlayan siber fiziksel sistemler Sanayi 4.0'in en temel güçlerinden birini oluşturmaktadır. Bugün gelişmiş teknoloji eseri bilişim sistemleri üretim süreçlerinin merkezine konumlanmış durumdadır. Siber fiziksel sistemler ve teknolojiler ile donatılmış makineler yeni ara yüzlere sahip olacaktır. Bunları eş zamanlı olarak kontrol etmek ve gerekli güncellemeleri yapmak konusunda daha hızlı ve esnek olabilmek adına değer zincirindeki ekipmanın yeni inovasyonlarla desteklenmesi ve siber fiziksel sistemlere uyumlaştırılması gerekmektedir. Endüstri 4.0'ın temeli, üretim süreçleri ve sistemlerin farklı ara yüzler üzerinden çeşitli ağlar ile bağlantı kurup çeşitli servislerle iletişim kurmasını sağlamaktır. Buna örnek olarak akıllı telefonlarımızdaki internet bağlantısı ile istediğimiz içeriklere ulaşabilmemiz, etrafımızdaki diğer akıllı telefonlarla çeşitli ağlar üzerinden iletişim sağlayabilmemiz gösterilebilir. Sanayi bağlamında incelendiğinde ise Endüstri 4.0'ın siber-fiziksel dünyalar arasındaki bağlantıları makinelere taşıdığı görülebilmektedir. Bu açıdan bakıldığında da örnek olarak “Akıllı Fabrikalar” gösterilebilir. Akıllı Fabrikalarda otomasyon, ekipmanların kendi aralarında haberleşerek işlevlerini aralarında belirleyip planlamaları anlamına gelmektedir. Örneğin, üretim sırasında hammadde eksikliği oluşursa gerekli sipariş otomatik olarak verilebilir, herhangi bir arıza durumunda o anda tespit yapılıp hızlıca giderilebilir. Siber fiziksel sistemler, aynı zamanda Ar-Ge ve pazarlama bölümlerinde de etkili farklar yaratabilmektedir. Herhangi bir yeni bölüm fiziki olarak kurulmadan önce bu sistemler sayesinde simüle edilip fizibilite çalışmaları bu sayede yapılabilmektedir. Özet olarak Endüstri 4.0 ve siber fiziksel sistemler çok daha hılı ve inovatif çözümlerin üretildiği, verimliliğin daha fazla olduğu bir gelecek yaratmaktadır.

Hızlı gelişmelerin yaşandığı teknoloji; üretim, dizayn ve hizmet anlayışlarını da beraberinde getirdiği yenilikler çerçevesinde değiştirmiştir. Bugüne kadar önemli sayıda üretici firma otomasyon sistemleri ile radyo frekans sistemi (RFID) kullanmaya başlayarak çoğu süreçlerini 'akıllı' işlemlere çevirmiş olsa da henüz teknoloji tam olarak beklentileri karşılayacak seviyeye erişmemiştir. Siber fiziksel sistemlerin esas hedefi tamamı ile 'akılllı izleme' ve 'akıllı kontrol' süreçlerinin kullanılıyor olmasıdır.

Siber fiziksel sistemlerin hem endüstri hem de günlük hayata nasıl yansıyacağı şu 3 aşama halinde özetlenebilir:

- İnovasyon, planlama ve pazarlama: Bu aşamalar bağlamında tüketicilerin kişisel tercihleri dahil analiz edilebilecek hale gelecek ve bu kapsamda üretim planlaması yapılarak tam otomasyon ile çalışan akıllı fabrikalar olacaktır.

- $\quad 7$ gün 24 saat tam otomasyonla çalışan fabrikalar: Planlaması bilgisayarlar tarafından yapılan makineler, daha yüksek verimlilik ile yüksek kalite üretim yapılmasını sağlayacaktır.

- $\quad$ Pazar ve nihai tüketiciler: Nesnelerin interneti sayesinde pazar, market, lojistik depolama alanlarındaki raflar dahil sensörlere bağlanarak sipariş akışının da otomatikleşmesine ve bu sayede tedarik zincirinin hızlanmasına olanak taniyacaktır.

Birbirlerine entegre olmuş ve bağlı çalışan bu sistemler beraberinde faydaların yanında bazı sakıncalar da ortaya çıkarmışıı. Bunların başında da siber güvenlik kavramı yer almaktadır.

\section{Siber Güvenlik}

Endüstri 4.0'dan önce bir fabrikanın güvenliği söz konusu olduğunda akıllara insan gücü ile sağlanabilecek koşullar gelmekteydi; ancak değişen hayat koşulları güvenlik algılarını da değiştirmektedir. Bugün artık fabrikalar gibi onlara yönelik saldırılarda 'akıllanmıştır'. Endüstri 4.0 devriminin lideri olan Almanya'da Deutsche Telekom'un 2015 yılında yayınladığı Siber Güvenlik Raporu’na göre, şirketlerin yüzde 90'nın siber saldırılarla karşılaştığı ve sadece yüzde 60'ı siber saldırılar karşısında hazırlıklı olduklarını onaylamıştır. Bu siber güvenlik raporunun da belirttiği gibi, Endüstri 4.0 devrimin tamamlanması ile siber saldırıların sıklığı da artacaktır (https://hbrturkiye.com/endustri-4-0-akilli-fabrikalarin-akilli-guvenligi). Siber ve fiziksel hayatın iç içe olduğu Endüstri 4.0 döneminde otomasyon sistemlerine yönelik olarak düzenlenebilecek saldırılar oldukça önemli tehlikelere yol açabilecek kadar tehlike arz etmektedirler. Örneğin, siber sistemler ile birbirine bağlı olarak çalışan makinelerin bulunduğu bir nükleer santrale yapılabilecek herhangi bir siber saldırının sebep olacağı zayiat kolay kolay telafi edilebilir boyutlarda olmayacaktır. Siber saldırıların fiziksel saldırılardan önemli bir farkı da nereden yapıldığının tespitinin çok zor olması ile bu saldırıların ışık hızında yapılıyor olmasıdır. Terörist bir örgüt herhangi 
bir ülkenin siber alanı üzerinden adres alarak, diğer bir ülkeye saldırabilir ve bu durum da hedef olan ülke ile saldırının yönlendirildiği siber alana sahip ülke arasında problemlere neden olabilir. Rusya ile Gürcistan arasında yaşanan 2008 yılı savaşında, Rusya'ya ait siber alandan Gürcistan'a yapılan siber saldırı bu durumun bir örneğidir. Rusya Gürcistan'a yönelik siber saldırılarda herhangi bir katkısı olmadığını belirtmiş olsa da, bu siber saldırıların Rusya'nın bilgisi dahilinde devlet destekli olarak mı yoksa ülkede ki terör saldırısı örgütleri tarafından mı yapıldığı kesinlik sağlanamamıştır (Gürkaynak, İren, 2011: 266).

Bugün içinde bulunulan konjonktürde ve yakında gelecekte de siber güvenlik sistemlerinin daha fazla geliştirilmesi ve arttırılması büyük bir ihtiyaçtır. Şu anda bu alanda oluşturulmuş bir kaynak kılavuz olmaması büyük bir eksiklik olmakla beraber farkındalığın arttırılarak yeni inovatif güvenlik önlemleri adına çalışmalar yapılmalıdır.

\subsubsection{Bulut Bilişim Sistemleri}

Bulut Bilişim, bilgisayarlar ve diğer cihazlar için, istenildiği zaman kullanılabilen, paylaşımlı veri işleme, depolama vb. yüksek işlem gücüne sahip internet tabanlı konfigüre edilebilir bilişim hizmetlerinin genel tanımıdır (https://tr.wikipedia.org/wiki/Bulut_bilişim). Bugün, insanlar her gün daha fazla miktarda veriyi saklamak istemektedir. $\mathrm{Bu}$ talebi karşılayab̄ilmek için de bilgisayar, telefon gibi cihazlarımızın hafızaları gittikçe güçlendirilmektedir. Bulut teknolojisi, internet üzerinden sağladığı depolama hizmetleri ve yüksek işlem kapasiteleri ile bu arayışa en iyi çözümü oluşturmuştur çünkü bu sayede depolama kapasitesi düşük bir cihazda dahi istenilen yerde ve zamanda arzu edilen verilerin istenilen şekilde kullanılmasına imkan sağlamaktadır.

\subsubsection{Büyük Veri}

Büyük veri, çok sayıda farklı verinin bir arada kullanılarak karar alınmasını sağlayan bir uygulamadır. Endüstri 4.0 ortamında faaliyet gösteren çoğu organizasyona sadece kendilerine ait olan veri tabanları yetersiz kalmaya başlamıştır. Bugünkü işletme ortamlarında, dış kaynaklardan gelen verilerin analiz edilmesi ile ortaya yeni bilgilerin çıkartılması ve organizasyon süreçlerinde bu bilgilerin kullanılması gibi bir ihtiyaç doğmuştur. Geleneksel veri tabanı sistemleri günümüzün bu ihtiyaçlarını karşılamakta yetersiz kaldığından artık çoğu büyük ölçekli organizasyon büyük veri alanında oldukça büyük yatırımlar yapmaktadır. Büyük veri sayesinde analiz etme süreçleri yalnızca geçmişteki performansı ortaya koymaz; ayrıca mevcut duruma uygun aksiyon alınmasını sağlar ve geleceğe yönelik tahminlerde bulunabilir (Lee, Kao, ve Yang, 2014: 8).

\subsubsection{3D Yazicılar}

3D Baskı; bir yazıcı kullanılarak bilgisayar destekli tasarım programları yardımıyla tasarlanmış herhangi bir elektronik datayı kalıp ve model ihtiyacı duymadan 3D datasını makineye yönlendirip kat kat malzeme ekleyerek 3 boyutlu üretimini gerçekleştirmektedir. 3D yazıcı ile üretim, yapılacak olan ürünün ham maddesi işlenerek mal üretilmeden önce ön şeklinin veya modelinin oluşturulması işlemidir (https://industryolog.com/dijital-sanayi-devrimi-4-endustri4-0da-3d-yazicilar/). Bu üretim teknolojisi katmanlı üretim olarak da bilinmektedir. Bu teknoloji sayesinde talebe göre en kısa süre içerisinde arzu edilen mamüller üretilebilir, hiçbir ekstra maliyete girmeden dizayn değişikliği yapılabilir. 3D yazıcıların kullanımı ile tasarımda pek çok sınır ortadan kalkacak ve her türlü hayata geçirilmesi zor olan karmaşık geometrik yapılar ürün haline getirilebilir olacaktır.

\subsubsection{Akıllı Robotlar}

Hammaddeyi işeyerek üretilen her türlü malın oluşumunda robotların kullanılması, 1970'li yıllara dayanmaktadır. Fakat gelişmiş sensör, aktüatör teknolojileri ve yapay zeka algoritmaları sayesinde her ortamda uyum içinde çalışabilen adaptif, esnek robotlar üretilmeye başlanmıştır. Geçmiş üretim hatları robotlara göre ayarlanıp düzenlenirken, günümüzde robotlar mevcut üretim sistemlerine ayak uydurmaktadırlar. Robotlar, gelişmiş sanal görüş yetenekleri ile parçaları ayırt ederek her ürün için farklı hareket edebilmektedir. Esnek yapıları sayesinde insanlarla yan yana çalışabilme özelliği taşımaktadırlar.

\subsubsection{Simülasyon ve Modelleme}

Simülasyon bugün bilgisayar oyunlarından, endüstri üretim süreçlerine pek çok farklı alanda kullanılan simülasyon yani modelleme; bir uygulamanın sebep sonuç ilişkilerini bilgisayar modeline uyarlayıp farklı koşullarda oluşabilecek davranış ve sonuçları gözlemlemeyi sağlayan bir sistemdir. Endüstri 4.0 için ise simülasyon ürün tasarımı ve geliştirme süreçleri açısından önem taşımaktadır. Bu modelleme uygulamaları sayesinde sanal ortak çalışmalar yapılabilecek ve bu da ürün geliştirme sürelerini kısaltırken aynı zamanda kalite kontrollerine olan mecburiyeti de azaltacaktır. Riskli işler için geliştirilen seçenekler işçiler için gerekli olan sağlık ve güvenlik standartlarının yerine getirilmesini de sağlayacaktır. Bunlar gibi üretim sürecinin farklı aşamalarında sağlanan pek çok fayda sonuç olarak verimliliği arttırırken, maliyetleri aşağıya çeker ve nihai olarak müşteri memnuniyetini arttırır. Endüstri 4.0 döneminde simülasyon bu bağlamda üretim süreçlerinin önemli bir yapı taşını oluşturur.

Endüstri 4.0 döneminin bütün bu teknolojik avantajlarından faydalanmak, yeni uygulama ve ekipmanları kullanmak isteyen sanayiciler ile müşterilerin kişiselleştirilmiş ürünlere olan talebi birbirine paralel olarak artış göstermektedir. 
Bu doğrultuda Gayri Safi Milli Hasıla'nın artması bu gelişmelerin getirmesi beklenen en etkili sonuçlardan biridir (Özhan, 2016: 55).

\subsubsection{Yatay ve Dikey Entegrasyonlar}

Endüstri 4.0 ile birlikte çok fazla büyüyen ve gelişen şirketin bu denli büyümesindeki en önemli etken bütünleşmek yani entegrasyondur. İşletmelerin birleşmesi büyümek için en hızlı ve etkili seçenek olduğu gibi diğer yöntemlere göre de daha avantajlıdır. Bütün organizasyonlar her daim varlıklarını korumak, büyüme hızlarını ve piyasa değerlerini arttırmayı hedeflemektedir. Bu amaçlar doğrultusunda da birleşmeleri tercih edebilirler. Şirket birleşmeleri yatay ve dikey olmak üzere 2 şekilde gerçekleşmektedir.

Yatay entegrasyonlar, aynı türde müssterilere sahip farklı organizasyonların birleşmesidir. Burada nihai hedef, şirketlerin ilgili pazardaki payının arttırılmasıdır. Yatay birleşmelerin sebebi tercih eden işletmelerin bulunduğu piyasaların çok hızlı değişmesi ve rekabetin çok fazla olmasıdır. Yatay entegrasyonun unsurları şu şekilde özetlenebilir:

- Organizasyonlar piyasalardaki belirsizliğin azaltılması ve AR-GE çalışmalarına ağırlık verilebilmesi için bu birleşmeyi tercih ederler.

- $\quad$ Risk oranı düştüğünden genelde riskli yatırımlarda bulunan işletmeler tarafindan tercih edilir.

- Aynı sektörde faaliyet gösteren birkaç işletme birleştiğinden pazarlama maliyetleri de düşer (Brettel, Friederichsen, Keller ve Rosenberg, 2014).

Dikey entegrasyonlar ise aynı pazarın farklı alt sektörlerinden müşterileri olan organizasyonların birleşme şeklidir. Buna örnek olarak araba üreticisi bir işletmenin tekerlek üreticisi ile entegre olması gösterilebilir.

Yatay ve dikey entegrasyonlar sayesinde Endüstri 4.0 ile yaşanan üretim süreci değişikliklerine hızlı uyum sağlanabilir, kaynak verimliliği arttırılabilir ve tedarik zinciri sistemlerinde maksimum verim ve iyileştirilme söz konusu olabilir.

\subsubsection{Endüstri 4.0'ın Getirileri}

Üretimin dijitalleşmesi üretim süreçleri ve iş modellerini değiştirecektir. İş hayatına dair yaşanacak değişikliklerin aşağıdakiler gibi olması beklenmektedir.

- $\quad$ Üretimde esneklik: Akıllı fabrikalar üretimin daha esnek bir yapıya sahip olmasını sağlayacaktır. Otomasyon sistemleri ve makineler ile yürütülen süreçlerde farklı ürünler aynı üretim süreçlerine dahil olabilecektir.

- $\quad$ Müşteri odaklı üretim: Müşteri talepleri doğrultusunda daha küçük ölçekli üretimler de prototip olarak yapılabilecektir.

- $\quad$ Üretim hızı: Dijital tasarımlar ve 3D yazıcılar sayesinde üretim süreçleri de kısalacaktır.

- $\quad$ Ürün kalitesi: otomasyon ve dijital üretim sayesinde büyük oranda düşen hata oranları daha yüksek kalitede ürünler elde edilmesini sağlayacaktır. Bu da fiyatların aşağı çekilmesi ve rekabetin artması anlamına gelmektedir.

- Verimlilik: Endüstri 4.0 uygulamalarının verimliliğe doğrudan ve dolaylı şekilde pozitif etkisi olduğu gözlemlenmiştir. Örneğin, bulut sistemleri ve büyük veri sayesinde öngörülen makine hataları engellenebilmekte ve bu sayede üretim oranında artış sağlanabilmektedir. İnsansız çalışan makineler sayesinde ise işçisiz fabrikalar kurulabilecek ve makineler sayesinde daha düşük hata oranları ile daha etkili çalışılabilecektir.

- Müşteriler: Ürünlerin tasarlanması aşamasına daha çok dahil olacak olan müşteriler, kendi tasarımlarını dahi kolay ve ucuz bir şekilde temin edebileceklerdir.

\subsubsection{Türkiye'de Endüstri 4.0}

Türkiye'de, ilk olarak en hızlı işleyen sektör olması sebebi ile otomotivde kullanılmaya başlanan Endüstri 4.0 teknolojileri, ürünlerin piyasaya sunulma sürelerini ciddi oranda kısaltmaktadır. Bu gelişmeler ve değişikliklerin diğer sektörlere de aynı etki ve hızda yansıması için devlet ve özel sektörün önde gelen isimleri tarafindan çeşitli forumlar düzenlenmekte, farkındalık çalışmaları yapılmaktadır.

Bilim Sanayi ve Teknoloji Bakanlığı tarafından 2016 Şubat ayı içerisinde yapılan Bilim Teknoloji Yüksek Kurulu toplantısının gündemi Sanayi 4.0 olarak belirlenmiştir. Bu toplantıda Endüstri 4.0 ile ilgili konuşma yapan Bilim Sanayi ve Teknoloji Bakanı Fikri Işık sanayideki yeni çağa uyumun devletimiz için önemine vurgu yapmış ve gerisinde kalmak gibi bir seçeneğimizin olamayacağını belirtmiştir. Bakanlığın bu kapsamda ortaya çıkan teknolojik gelişmeler yapay zeka, akıllı robotlar, 3-D yazıcılar, nesnelerin interneti, büyük veri ve bulut sistemleri gibi olguların üzerinde durularak bu bağlamda 25 Öncelikli Dönüşüm Programı, 64. Hükümet Programı ve Eylem Planı ile Türkiye'nin çok ileri bir noktaya taşınması için çalışıldığından bahsedilmiştir. Buna göre Türkiye'nin sanayi stratejisi uzun dönemde orta yüksek ve yüksek teknolojili ürünlerde, Afro-Avrasya'nın tasarım ve üretim üssü olmayı hedeflemektedir. Aynı zirveye konuşmacı olarak katılan Başbakan Binali Yıldırım da Türkiye'nin esas hedefinin teknolojik, katma değeri arttıracak, yenilikçi, milli ve yerli mamüller yaratmak olduğuna dayanmış ve bu bağlamda da veri merkezlerinin önemine değinerek bu konuda yapılacak girişimleri devletin her şekilde destekleyeceğini açıklamıştır. 
Bugün Türkiye'de, bahsedilen bu hedeflere ulaşılmış olmadığı gibi gecikmeler arttıkça altından kalkılması gerekecek yük de artacaktır. Ülkemizde bugün Endüstri 4.0 kapsamında öncelikli olarak yapılması gereken yeni teknolojik altyapıların ve bu altyapılar ile çalışabilecek uzman kadroların oluşturulmasıdır. Küresel pazarlarda rekabet edebilecek güçte olmak için bu yeni sanayi döneminin getirilerini özümsemek hayati öneme sahiptir çünkü inovatif olamayan organizasyonlar kısa dönemde piyasadan silineceklerdir.

Endüstri 4.0 devriminin hayata geçirilmesinde ivme kazanılması organizasyonların dijital dönüşümlerini tamamlamış olmalarına bağlıdır. Bu dönüşümü hem altyapı hem de organizasyon kültürü bağlamlarında bünyesine almamış olan işletmelerin yeni çağı yakalaması olanaksızdır. 2016 tarihli “Türkiye'deki Dijital Değişime CEO Bakışı” adı verilen rapor, Türkiye'de ki 58 şirketin üst düzey yöneticileriyle yüz yüze yapılan mülakatlar neticesinde meydana gelmiştir. Bankacılık, Holding, Perakende, Hızlı Tüketim ve Telekomünikasyon gibi önemli sektörlerde faaliyet gösteren şirketlerle çalışmalar yapılmıştır. Türkiye' de ki bu üst düzey yöneticilere göre, şirketlerinin dijital stratejilerinin şirket çalışanları tarafından anlaşılma tahmini \%66 civarlarındadır ve dijital değişime yön veren C seviye yönetici varlığı da \%38 yükselmiştir. Bu şirket üst düzey yöneticilerine şirketlerinin dijital yetkinlik seviyesi sorulduğunda ise; \%7’si giriş, \%59'u gelişmekte olan ve \%34'ü gelişmiş bir dijital yapıya sahip olduklarını söylemiştir. Araştırmanın en kritik sorularından biri, şirketlerin yatırımlarının ne kadarlık bir bölümünü dijital gelişime tahsis ettikleridir. Ortalama sayı \%27 olmuştur ve bu oran ümit vaat etmektedir (http://www.endustri40.com/endustri-tarihine-kisa-bir-yolculuk/).

\section{ENDÜSTRİ BAĞLAMINDA TÜRKIYE'NIN KONUMU}

Sanayi sektörü, büyük bir hızla ilerleyen teknolojinin desteğini de arkasına alarak yeni sanayi reformunu gerçekleştirmektedir. Bu yeni dönem yani Endüstri 4.0 döneminin pek çok faktörü ayrı ayrı hazır durumda; ancak bu faktörlerin bir araya getirilerek sistemleri ve üretim işleyiş süreçlerine entegre edilmesi gerekmektedir. Türkiye'nin bu süreçte bulunduğu noktayı anlamak için hem ülkemizdeki hem de dünyadaki durumun analiz edilerek karşılaştırılması ve bu doğrultuda ilerlemek için bir yol haritası çıkartılması gerekmektedir.

\subsection{Dünyada Endüstri 4.0}

Endüstri 4.0 bir bütün olarak ele alınıp değerlendirilmesi gereken, içinde birden fazla farklı teknolojik unsurları barındıran bir vizyondur. Bu teknolojik gelişmelerin tek başına var olması, bir araya getirilip üretime entegre edilmediği sürece Endüstri 4.0'ın uygulamaya konulmuş olduğu söylenemez. Endüstri 4.0'a dair en önemli ve olmazsa olmaz teknolojik gelişme dijitalleşmedir. PwC 2016 yılında, 26 ülkede 9 farklı sektörde, 2000'i aşkın şirketle Endüstri 4.0 çalışması yapmıştır. Bu araştırmaya katkı sağlayan şirketlerin \%33'ü kendilerini yüksek düzeyde dijitalleşmiş olarak değerlendirmektedir. 5 yıl içerisinde ise araştırmaya katılan bu şirketlerin $\% 72$ 'si üst seviyede dijitalleşmiş olmayı ummaktadır (http://www.endustri40.com/dunyada-endustri-4-0). İlgili altyapıların tamamlanmış olması Endüstri 4.0 reformunun gerçekleşmesi için temel gerekliliktir. Dolayısıyla bu kapsamda çalışmaya erken başlayan ülkeler ve kurumlar bu açıdan çok daha avantajlı konuma sahip olacaklardır. PwC'nin Çin'den İsviçre'ye, Almanya'dan Meksika'ya pek çok ülkeyi kapsayacak şekilde yapmış olduğu bir araştırmada çalışmada şirketlere, önümüzdeki 5 yıl içerisinde dijitalizasyon sayesinde gelirlerinde ne kadar bir artış ve giderlerinde ne kadar bir tasarruf bekledikleri sorulmuştur. Endüstri 4.0 devrimine ilk olarak uyum sağlama çalışmalarını başlatan şirketlerin \%27'sinde, \%30'un üzerinde gelir artımı ve \%30'un üzerinde gider artırımı umudu vardır. Bu tahmin tüm şirketler arasında \%10'a inmektedir (http://www.pwc.com/gx/en/industries/industry-4.0.html). Bu verilerden anlaşılmaktadır ki dijitalleşme yolunda öncelikli olarak çalışmaya, adımlar atmaya ve yatırım yapmaya başlayan kuruluşların verimliliklerini büyük oranda arttırması beklenmektedir. İşletmelerin en temel hedeflerinden biri her daim minimum sürede az maliyet ile yüksek kalitede ürün imal etmek olacaktır. Günümüzde bu amaca ulaşmak Endüstri 4.0 teknolojileri ile mümkün olabilmektedir. Boston Consulting Group'un (BCG) Almanya üretim sanayi üzerinde yaptığı bir çalışma da bu sonuçların doğruluğunu ortaya koymaktadır. Buna göre Endüstri 4.0 ile beraber verimlilik, gelir, istihdam ve yatırım konularında olumlu gelişmeler yaşanacaktır ve önümüzdeki 5-10 yıllık süre içinde Endüstri 4.0 vizyonunu benimseyecek kuruluş sayısı artacaktır. Bu bağlamda daha yüksek verimlilikle çalışmaya başlayacak olan işletmelerin sanayi sektöründe 90-150 milyar Euro civarında kazanç sağlaması beklenmektedir (http://www.endustri40.com/dunyada-endustri-4-0). İşletmelerin Endüstri 4.0'1 üretimlerine entegre edebilmeleri için gerekli olan yeni teknolojilere yapacakları yatırımlar ile, tüketicilerin kişiselleştirilebilir ürünlere olan artan istekleri, yılda 30 milyar Euro civarında gelir artışını destekleyecek unsurlardır ki bu miktar Alman GSMH'sında \%1'lik bir katkı anlamına gelmektedir. Dünyada Endüstri 4.0'a geçiș tamamlandığında üretimin en büyük kısmının akıllı robotlar tarafından yapılacak olması, akıllarda istihdam ile ilgili soru işaretlerine sebep olmaktadır; ancak BCG'nin Almanya imalat sanayi üzerinde yaptığı bir araştırma korkulanın tam aksine bir tablo ortaya koymuştur. Buna göre önümüzdeki 10 yıllık süreç içinde istihdamda \%6 oranında bir artış beklenmekte, özellikle de yazılım geliştirme ve bilgi işlem alanlarında iş gücü arayışı artacak, bu esnada da düşük yetkinlik seviyesindeki işlere olan ihtiyaç düşecektir (https://www.bcg.com/publications/2015/engineered_products_project_business_industry_4_future_productivity_gr owth_manufacturing_industries.aspx).

\subsubsection{Almanya Örneği}


Almanya'nın endüstriyel dönüşümü örnek olarak incelendiğinde ciddi bir ekonomik yükseliş beklenmektedir. BCG araştırmasına göre, Endüstri 4.0'1 entegre etmeye başlayan Alman imalat sektörünün toplam üretim maliyetinin \% 5-8 düşmesi ile beraber, önümüzdeki 10 yıl içinde 90-150 milyar Euro arasında verimlilik kazancı elde edecektir. Malzeme giderleri hariç, operasyon maliyetlerinin \% 20 azalması bekleniyor. Bu verimliliği kazanabilmek için ise Alman sanayicilerinin üretim sistemlerini ve süreçlerini Endüstri 4.0'a uyumlu hale dönüştürmek için önümüzdeki 10 yıllık dönemde 250 milyar Euro yatırım yapması bekleniyor. Buna ek olarak, şirketlerin ileri teknolojilere, tüketicilerin ise özelleştirilmiş ürünlere olan talebinin artmasıyla, bu artışın 300 milyar Euro'luk ek gelir sağlaması ve büyümedeki bu artışın da aynı dönemde istihdamda \% 6'lık bir artışa sebep olması bekleniyor (TÜSİAD, 2016: 35). Endüstri 4.0 Almanya'da doğmuş ve fillizlenmiş bir kavram olmasına karşılık bugün artık bu vizyonun öncüsü konumunda olmadığını McKinsey'nin ABD, Almanya ve Japonya üzerinde yapmış olduğu bir çalışmanın sonuçları ortaya koymuştur. Alman üreticilerinin Endüstri 4.0'a yatırımlarında şampiyonluğa oynamadığını ortaya çıkarmıştır. Almanya, Ar-Ge harcamalarının \% 15'ni Endüstri 4.0 için tahsis ederken, Amerika' da ise bu oran \% 29 'dur. Ayrıca Amerika’nın Endüstri 4.0 ile ilişkili gelirlerinin toplama olan oranı \%30 iken bu oran Almanya'da \%19, Japonya'da ise \%11 olarak görülmektedir (http://www.endustri40.com/dunyada-endustri-4-0). Endüstri 4.0'1n getirdiği yeniliklere bağlı olarak artık üretim süreçlerinde eski teknolojiye ait geleneksel yöntemlerin kullanılmaya devam edilemeyeceği görülmektedir. 2020'ye kadar yeni reformları bünyelerine katacak olan şirketlerin \%80'i iş modellerinin de bu reformlar ile beraber yenileneceğini öngörmektedir. $\mathrm{Bu}$ değişikliklere paralel olarak yeni iş modelleri yeni firsatları da beraberinde getirebilecektir. Endüstri 4.0 ile bugünün fabrikaları uygulanmasıyla, şu anki fabrikaların büyük bir değişim geçireceği gerçekliğinin yanı sıra, bu devrimin getirdikleriyle geleceğin fabrika modellerini de ortaya koyacaktır. Dünyada Endüstri 4.0'a dair var olan bu büyük ve iddialı beklentilere rağmen üretimler hala tam olarak dijitalleşmemiştir. Bugün gelinen nokta göz önünde bulundurulduğunda özellikle de makine ve endüstri mühendisliğinin dijitalizasyona dair kat etmesi gereken yol uzun görünmektedir. Gelecekteki fabrikalarının otomasyon ve internet ağları ile birbirine bağlı yazılımlar tarafından işletilmesi öngörülürken, dünyanın ilk akıllı fabrikasının yakın bir gelecekte kurulacağını söyleyen Alman Yapay Zekâ Araştırma Merkezi’nden (DFKI) Prof. Detlef Zühlke Almanya'da hâlihazırda bir akıllı fabrika modeli üzerinde çalışmaktadır. Bu kapsamda arttırılmış gerçeklik, akıllı kalite kontrol sistemleri, lazer ile çalışan üretim bantları, yürütmede olan projelerden bazılarıdır. Şuanda bu sistemlerin doğru ve güvenli şekilde çalışması için siber güvenlik araştırmalarının yanı sıra üretim sürecinde harcanan enerji miktarını minimum düzeye indirebilmek adına enerji depolama çalışmaları da süregelmektedir. Bu süreçlerin toplu şekilde yönetilebilmesi ise elbet bulut ve büyük veri sistemleri sayesinde olabileceğinden bu alandaki yatırım ve çalışmalar da devam etmektedir. Bugün sanayiye baktığımızda dünyada Endüstri 4.0 konusunda bazı ülkelerin daha ileride, bazılarının ise henüz başlangıç aşamasında olduğu görünmektedir; ancak genel tablo içerisinde Endüstri 4.0'1 tam olarak özümsemiş ve uygulamaya koymuş bir ülke yoktur. Bunun sebebi ise yeni teknolojilerin bütünü ile uygulanabilmesi için altyapıların tam olarak hazır ve yeterli olması gerektiğidir. Bugün çoğu ekonomi altyapısını oluşturmakta ve kendisini yeni sanayi dönemine hazırlamaktadır. Bu hazırlıkları ilk olarak tamamlayan ülke ve ekonomiler diğerlerinden birkaç adım ileride olacaktır. Dolayısıyla küresel ticaret boyutunda rekabet avantajını ellerinde bulunduracak ve ekonomilerini büyütmek bağlamında diğerlerinden daha güçlü konumda bulunacaklardır.

\subsection{Endüstri 4.0'da Türkiye'nin Konumu}

Türkiye bugün son endüstri devrimi konusunda fazla mesafe kat eden ülkelerden biri konumunda değildir. Eğer Endüstri 4.0'1 uygulamaya geçirmek için gerekli teknolojik altyapıların oluşturulup hazırlanması ve yeni dönem için yeterli donanıma sahip uzmanların yetiştirilmesi için geç kalınırsa bu durum Türkiye'nin üstlenmekte oldukça zorlanacağı bir sorumluluk olacaktır. Bugünkü aşamada, küresel boyutta rekabet avantajını elinde tutabilmek ve gücünü koruyabilmek isteyen her ekonomik güç gibi Türkiye'nin de en önemli misyonu Endüstri 4.0'1n getirdiği gereklilikleri yapmaktır. Bunun için de Türkiye'nin öncelikli olarak kendi adına bir durum tespiti yapması ve bu doğrultuda stratejik bir yol çizmesi gerekmektedir.

Sanayi alanında söz sahibi, sanayi devi ülkeler başta Almanya olmak üzere 2013 yılından itibaren bu yeni kavram çerçevesinde çalışmalara başlamışlardır. Türkiye'de ise bu kavrama dair ilgi anca 2015 yılından itibaren başlamıştır. Bunu en açık şekilde Endüstri 4.0 konusunda Türkiye'den yapılmış olan Google aramalarından gözlemlenebilmektedir. 


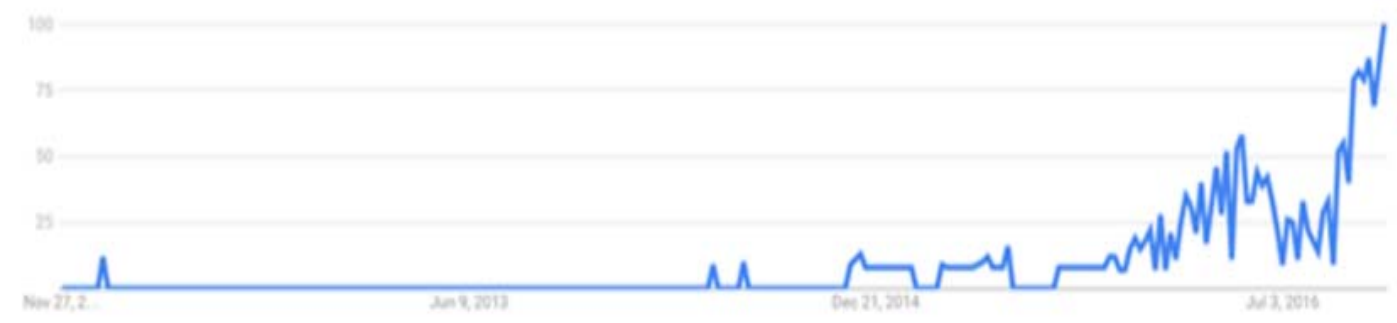

Şekil1: Endüstri 4.0’ın İnternette Aranma Trendi Kaynak: (http://www.endustri40.com/turkiyede-endustri-4-0).

Endüstri 4.0 reformunun uygulanması ve tamamlanabilmesi için en önemli ön koşullardan bir tanesi, kurumların dijital reformlarını tamamlamış olmasıdır. Dijitalleşme sürecini hem altyapılarına hem de şirket kültürlerine uyarlamamış ve bu süreci tamamlayamamış organizasyonlar Endüstri 4.0'1 yakalayamayacak ve rekabet edemeyerek belki de yok olmaya mahkum kalacaktır. TÜSİAD, Samsung Türkiye, Deloitte Türkiye ve GFK Türkiye'nin işbirliğiyle düzenlenen, 2016 tarihli “Türkiye'deki Dijital Değişime CEO Bakışı” adlı raporda, Türkiye'de faaliyet göstermekte olan 58 işletmenin üst düzey yöneticileriyle yapılmış olan mülakatlar sonucunda ortaya konmuştur. Bankacılık, Holding, Perakende, Hızlı Tüketim ve Telekomünikasyon gibi mühim ve büyük sektörlerde faaliyet gösteren işletmelerle bir çalışma yapılmış ve onların üst düzey yöneticilere göre, kurumlarının dijital stratejilerinin personel tarafından anlaşılma oranı \% 66 civarındadır. Bu dijital değişimi sağlayan C seviye yönetici oranının da \% 38 civarında olduğu belirtilmiştir. Şirket yöneticilerine, şirketlerinin dijital yetkinlik seviyesi sorulduğunda ise; \%7'si giriş, \%59'u gelişmekte olan ve \%34'ü gelişmiş bir dijital yapıya sahip olduklarını belirtmiştir. Araştırmanın kritik sorularından biri, şirketlerin yatırımlarının ne kadarını dijital gelişime ayırdıklarıdır. Ortalama olarak bu oran \%27'dir ve ümit vaat etmektedir (http://www.endustri40.com/turkiyedeendustri-4-0). Sanayi reformunun tamamlanması için özel sektörün teknolojiye yapacağı yatırımlar, devletin bu alanda başarılı bir vizyonu olmadığı sürece anlamsız kalacaktır. 2016 yılının Şubat ayında yapılan Bilim Teknoloji Yüksek Kurulu toplantısında bu konuya dair bazı kararlar alınmıştır. Siber fiziksel sistemler, yapay zeka, sensör, robot teknolojileri, Nesnelerin İnterneti, Büyük Veri, siber güvenlik ve bulut bilişim gibi konulardaki yetkinliklerin artırılmasını hedefleyen Ar-Ge çalışmalarının desteklenmesi ve lider teknolojilerin yerli şirketler tarafından üretilebilmesine imkan tanıyacak gerekli teşvik programlarının geliştirilmesi yönünde alınan karar; Türkiye'nin Endüstri 4.0 vizyonuna dair farkındalığının yüksek düzeyde olduğunu ortaya koymaktadır. TÜBİTAK tarafından yapılan ve Türkiye'nin sanayi devrimleri bağlamındaki konusunu tespit etmeyi amaçlayan çalışmaya göre Türkiye bugün dijitalleşme açısından Endüstri 2.0 ile Endüstri 3.0 arasında bir konumda bulunmaktadır (http://www.endustri40.com/turkiyede-endustri-4-0). Türkiye, coğrafi konumunun sağladığ kolaylıklar ve düşük maliyet ile üretim yapılması sayesinde küresel ticarette güçlü bir rakip pozisyonunu almıştır. Türkiye'nin bu rekabet gücünü elinde bulundurmaya devam edebilmesi için büyük bir kısmı ithalata dayanan üretimini geliştirmek zorundadır. Ayrıca yüksek teknolojili ürün üretiminde Türkiye, az gelişmiş bir profil çizmektedir. Toplam ihracatındaki yüksek teknolojili ürün ihracatının oranı yalnızca \%4'ünün olması Türkiye'nin eksikliğini ortaya koymaktadır. Dolayısıyla üretimdeki ithalat oranının aşağı çekilerek daha bağımsız ve donanımlı hale getirilmesi gerekmektedir.

\subsection{Durum Değerlendirmesi}

Sadece ekonomi ve üretimi değil, sosyal hayatı, alışkanlıkları hatta toplumun ihtiyaçlarını dahi değiştiren sanayi devrimleri hayvan ve insan gücüne dayanan üretim dönemlerinden 1. Sanayi Devrimi ile bugün otomasyon, insansız araçlar ve nesnelerin interneti gibi kavramlar ile Sanayi Devrimi yani Endüstri 4.0 aşamasına gelmiştir. 4. Sanayi Devrimi, ileri teknoloji temelinde ürün ve hizmet üretim ve sunumu için sürekli, sürdürülebilir ve verimli insan-makine-veri ilişkisini sağlamayı ve bu bağlantıların sonucunda ortaya çıkacak çok büyük miktarlardaki veriyi işleyerek aksiyona dair bilgiyi otomatik olarak üretebilmeyi amaçlamaktadır. Bugünün inovatif teknolojileri bu hedefe yönelik makine, ürün ve hizmetleri sunmaya başlamıştır. Almanya'da başlayan bu yeni süreç bütün dünyada hızla yayılmaya başlamış ve küresel ekonomi ve ticarette söz sahibi olmak isteyen devletler tarafından uygulama çalışmaları yapılmaya başlanmıştır. ABD ve Japonya üzerinde yapılan çalışmalara göre Endüstri 4.0 konusunda başı çeken ülke Almanya değildir. Amerika bugün Almanya'dan daha ileri bir noktaya gelmiştir. Bu durum göstermektedir ki kavramın nerede filizlendiğinden çok ona nerede daha çok yatırım yapıllyor olduğu önem kazanmıştır. 
Endüstri 4.0 konusunda bugün gelinen nokta için ise çok net bir değerlendirme yapmak mümkün görünmemektedir. Çünkü devrim henüz tamamlanamamıştır. Bugün hala hazırlık ve alt yapı çalışmalarının süregeldiği bir dönem içerisinde olduğumuz söylenebilir. Dünyadaki her ülke farklı aşamalarda bulunmakta olsa da bütünsel olarak otomasyona geçmiş ve yeniçağa tamamen dönmüş bir ülke henüz yoktur. Ancak 2020 yılına kadar teknolojik gelişmelerin daha da ivme kazanması ve 2020'de çok farklı bir tablo içerisinde yer alınıyor olunması beklenmektedir. Bu farklı tablo hem üretim sistemleri, fabrikalar, ürün ve hizmetler de hem de devletlerin ekonomik ve sosyal refah seviyelerinde gözlemlenebilecektir. Türkiye'de Endüstri 4.0'a dair ileri teknoloji henüz en belirgin ve etkin şekilde otomotiv sektöründe kullanılmaktadır, diğer sektörlerde de ileri teknoloji ve otomasyona geçilmesi ile verimlilik ve kazançların arttırılması hedeflenmektedir. Aksi takdirde Türkiye, lojistik konumundan ötürü elde etmiş olduğu güçlü rekabet avantajını, Endüstri 4.0 ile ucuzlayacak iş gücü sebebi ile kaybedebilir.

Önümüzdeki dönemde yaşanması beklenen ve temelleri atılmış olan değişikliklerin mesleki hayatlar üzerinde de bir takım etkileri olacaktır. Bugünün bazı iş alanları 2020’ye gelindiğinde ortadan kalmış olacakken şu anda olmayan yeni iş alanları da ortaya çıkacaktır.

- Robot Koordinatörlüğü: Yakın gelecekte işletmelerin her departmanında faal olması hedeflenen robotların artacak kullanımları, bu robotları kullanacak koordinatörlere olan ihtiyacı da arttıracaktır. Bu koordinatörler akıllı robotların kullanımları, bakımları, servis ihtiyaçları gibi gereksinimleri karşılamak üzere görev yapıyor olacaklardır.

- IT/IOT Çözüm Mimarlığı: Gün geçtikçe daha karışık bir hal alan IT sistemleri, tüm sistemlerin tasarımlarının sorumluluğunu üstlenen IT çözüm mimarlarına olan ihtiyacı arttıracaktır.

- Şebeke Yönetim Mühendisliği: Akılı şebeke sistemlerinin etkisini evlerimizde de görebilmekteyiz. Bütün elektrikli ev aletlerinin birbirleriyle iletişime geçmesi güç kullanımına da fayda sağlayarak enerji kullanımında tasarruf edilmesini sağlayacaktır. Bu tasarrufun gerçekleşebilmesi için yetkin şebeke yöneticilerine ihtiyaç olacaktır.

- Giyilebilir Teknoloji Tasarımcıları: Giyilebilir teknoloji üzerine yatırımlar yapılmaya başlamıştır dolayısıyla günlük hayatlarımızın bir parçası olması çok da uzak bir zaman değildir. Kalp ritmi, harcanan enerji gibi verileri telefonlarımızdan takip etmemize olanak tanıyan bileklikler bu teknolojiye bir örnektir. Bu gibi ürünlerin çeşitliliğinin artacağı aşikardır; ancak teknolojik özelliklerinin yanında tasarımı da iyi olmadığı takdirde bu aksesuar ve kıyafetleri pazarlamak oldukça zor olacaktır. Bu sebeple giyilebilir teknolojiyi daha cazip kılacak tasarımları yapacak tasarımcılara ihtiyaç doğacaktır. Bu da yeni bir meslek olarak karşımıza çıkacak bir alan olarak değerlendirilmelidir.

Bugünün global ekonomisinin karışık ve zorlu yapısı kıt kaynakların etkin, verimli ve dengeli şekilde kullanılmasını zorunlu kılmaktadır. Ekonomik bağlamdaki zorlukların üzerinden gelebilmek için sürdürülebilir başarıyı yakalamış bir ekonomi ve gelişme oluşturmak da olmazsa olmaz bir koşul haline gelmiştir. Bu giderek gelişen ilişki ağlarının başarısında, özel sektör ve kamunun sürekli işbirliği içinde olması verimli politika ve uygulamalar için adeta önkoşul halinde Türkiye'nin de endüstri, teknoloji ve kalkınma stratejilerinde verimlilik ve ihtiyaç temelli politikalara odaklanarak hareket etmesi gerektiği görülmektedir. Öncelikle ülke ekonomisinin orta gelir seviyesinden çıkarılması, etkinlik esaslı ekonomilerden bilgi toplumu ve ekonomisine geçiş yapabilmesi de doğru tanımlanmış ihtiyaçlara dair etkili stratejiler oluşturabilmesine bağlıdır. Bu kapsamda da ihtiyaçların açık şekilde tanımlanması; kamu, özel sektör ve sivil toplum kuruluşlarının iş birliği içerisinde çalışmaları gerekmektedir. Türkiye'nin yeni gelişen bu sanayi devrimini kaçırmaması çok kritik bir öneme sahip; daha önceki endüstriyel atılımlarda geride kalmanın dezavantajlarını hâlâ yaşayan Türkiye'nin bu treni kaçırma lüksü yoktur. Özetle, dünya büyük bir hızla bilişim teknolojilerini farklı alanlara adapte ederek yeni bir endüstriyel döneme girmiştir ve Türkiye'nin de bu yönde adımlar atması gerekmektedir.

\section{TÜRKIYE'DE ENDÜSTRİ 4.0 YÖNETIMI UYGULAMALARI} 3.1. Yöntem

Araştırmada nitel araştırma tekniği kullanılmıştır. Nitel araştırma bir sosyal olayı doğal ortamı ve doğal oluşumu içinde tasvir eden bir araştırma türüdür. Deneysel nicel araştırmalar gibi olayın değişkenleriyle oynamaz. Bir durumu ilişki bağlantıları içinde anlamaya çalışır. Nitel araştırmalarda üç temel veri toplama yöntemi vardır; gözlem, mülakat ve doküman inceleme (Patton, 1990). Bu çalışmada mülakat tekniği kullanılmıştır.

Araştırmanın örneklemini, Türkiye'de Endüstri 4.0 konusunda öncülük eden 6 işletmenin üst düzey yöneticileri oluşturmaktadır. 
Endüstri 4.0 konusunda öncü 6 işletmenin üst düzey yöneticileri ile bire bir mülakat yapılmıştır. Mülakatta sorulan sorular şunlardır;

1- Dijitalleşme için Endüstri 4.0'ın ilk adımıdır diyebilir miyiz?

2- $\quad$ Endüstri 4.0 ile beraber hangi meslek gruplarına talebin artacağını düşünüyorsunuz?

3- $\quad$ Endüstri 4.0 ile ilgili yanlış bilinenler nelerdir?

4- $\quad$ Türkiye'de Endüstri 4.0'ın anlam ve önemi nedir?

5- Real time verilerin şirketler için önemi nedir?

6- $\quad$ Adını bilmediğimiz yeni meslek gruplarının uzmanlık alanlarının ne olacağını düşünüyorsunuz?

7- Geleceğin fabrikalarını nasıl hayal ediyorsunuz?

Yapılan mülakat sorularına verilen cevaplardaki ortak anahtar kelimeler özet olarak tablo 1'de sunulmuştur.

Tablo 1: Karşılaştırmalı Yorum Tablosu

\begin{tabular}{|c|c|c|c|c|c|c|}
\hline & $\underset{\longleftarrow}{\longleftarrow}$ & 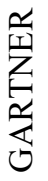 & 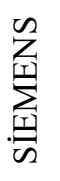 & $\begin{array}{l}\mathbb{Z} \\
0 \\
0 \\
0 \\
0\end{array}$ & 㐾 & 兒兒 \\
\hline \multicolumn{7}{|l|}{ SORU 1} \\
\hline EVET & & & $\mathrm{X}$ & $\mathrm{X}$ & $\mathrm{X}$ & $\mathrm{X}$ \\
\hline HAYIR & $\mathrm{X}$ & $\mathrm{x}$ & & & & \\
\hline \multicolumn{7}{|l|}{ SORU 2} \\
\hline MULTİDİSİPLINER & & & $\mathrm{X}$ & $\mathrm{X}$ & $\mathrm{X}$ & \\
\hline YAPAY ZEKA PROGRAMCISI & & $\mathrm{X}$ & & & & \\
\hline VERİ BİLIMCİ & $\mathrm{X}$ & $\mathrm{X}$ & & & $\mathrm{X}$ & $\mathrm{X}$ \\
\hline ROBOT BAKIM TEKNISYENI & & & $\mathrm{X}$ & & & \\
\hline ROBOT AVUKATI & & & & & $\mathrm{X}$ & \\
\hline SİBER GÜVENLİK UZMANI & & $\mathrm{X}$ & & & & \\
\hline \multicolumn{7}{|l|}{ SORU 3} \\
\hline PAZARLAMA TEKNİĞİ & $\mathrm{X}$ & & & & & \\
\hline İŞSİZLİK & $\mathrm{X}$ & & $\mathrm{X}$ & & $\mathrm{X}$ & $\mathrm{X}$ \\
\hline DİJITTALLEŞME & & $\mathrm{X}$ & & $\mathrm{X}$ & $\mathrm{X}$ & \\
\hline \multicolumn{7}{|l|}{ SORU 4} \\
\hline KALKINMA PLANI & & $\mathrm{X}$ & & $\mathrm{X}$ & & \\
\hline KAÇIRILMAYACAK & $\mathrm{X}$ & & $\mathrm{X}$ & & $\mathrm{X}$ & $\mathrm{X}$ \\
\hline \multicolumn{7}{|l|}{ SORU 5} \\
\hline YAKIT & $\mathrm{X}$ & & & $\mathrm{X}$ & & \\
\hline İZLENEBİLİRLİK & $\mathrm{X}$ & $\mathrm{X}$ & $\mathrm{X}$ & & $\mathrm{X}$ & \\
\hline TAHMIN & $\mathrm{X}$ & $\mathrm{X}$ & & $\mathrm{X}$ & $\mathrm{X}$ & $\mathrm{X}$ \\
\hline \multicolumn{7}{|l|}{ SORU 6} \\
\hline HUKUK & $\mathrm{X}$ & & $\mathrm{X}$ & & & \\
\hline İNSAN KAYNAKLARI & & & & & $\mathrm{X}$ & \\
\hline YAZILIM & $X$ & $\mathrm{X}$ & & $\mathrm{X}$ & & $X$ \\
\hline GÜVENLİK & $\mathrm{X}$ & $\mathrm{X}$ & & & & \\
\hline \multicolumn{7}{|l|}{ SORU 7} \\
\hline ÇEVRECİ & $\mathrm{X}$ & & & & $\mathrm{X}$ & $\mathrm{X}$ \\
\hline YAPAY ZEKA & & $\mathrm{X}$ & & $\mathrm{X}$ & $\mathrm{X}$ & $\mathrm{X}$ \\
\hline MAVİ YAKA & & & & & $\mathrm{X}$ & $\mathrm{X}$ \\
\hline KARANLIK & $\mathrm{X}$ & & $\mathrm{X}$ & & & \\
\hline
\end{tabular}

\subsection{Araştırma Verilerinin Analizi}

Araştırmaya katılan şirketler, bu yeni endüstriyel devrimin temsilcilerinden değerli birkaçı olarak, Türkiye'nin Endüstri 4.0 rehberi olma vizyonunu üstlenmektedirler. Bu süreçte, süre gelen etkinlikler ile bilgiyi aktarmaya ve farkındalığ 
Karşılaştırmalı mülakatlardaki cevaplardan anlaşılmaktadır ki, firmalar genel itibari ile Endüstri 4.0’ı kısaca, sadece fabrika ve işletmelerin dijitalleşmesi olarak değil, bir üretim hattında kalmayan ve bu dönüşümü uçtan uca bütün süreçlere uyarlayan, sanayinin dijitalleşmesi olarak tanımlamaktadırlar. Devrim niteliğindeki bu dönem, Büyük Veri, Nesnelerin İnterneti, Bulut Bilişim, Arttırılmış Gerçeklik, Akıllı Robotlar, Siber Güvenlik gibi alanların bileşenlerini içinde barındırmaktadır. Bu bileşenler yüksek verimlilik, daha nitelikli insan kaynağı, süreçlerinin daha kolay ve daha çok üretim sağlanması gibi pozitif süreçleri beraberinde getirmektedir.

Araştırma bulguları, Endüstri 4.0 ile beraber \%70'e kadar enerji tasarrufu sağlanabileceğini göstermektedir. Geleceğin fabrikaları, "Ișıksız Fabrikalar" olarak adlandırılmaktadır.

Araştırmaya katılan şirketler, 1. ve 2. Sanayi devrimini yakalayamayan Türkiye’nin şu anda Sanayi 2.5 diyebileceğimiz bir konumda olduğunu vurgulamaktadır.

Araştırma bulguları bize, ülkemizde Endüstri 4.0'ın farkındalığının oluşmuş durumda olduğunu ve gerek şirketler, gerekse devlet kurumlarında, Türkiye'nin yol haritasının oluşturulduğunu ve çalışmalara başlanıldığını göstermektedir.

Araştırma bulguları neticesinde firmalar genel itibari ile Endüstri 4.0 ile beraber üretimde kas gücü yerini, beyin gücüne bırakacağı konusunda hemfikir durumdadır. Bu sayede üretimdeki hataların azalması ve verimin artması gibi pozitif oluşumlar göze çarpmaktadır.

Mülakatlar sonucunda, bu değişime ayak uydurmak konusunda ülkemizde büyük farkındalıklar olduğu ve bu devrimi kesinlikle ıskalamamız gerektiği vurgulanmıştır. Bu değişimi ülke olarak yakalamak zorundayız. Türkiye'nin 2023'te, dünyanın en büyük on ekonomisi arasına girebilmesi için yılda ortalama \% 8,5 oranında büyümesi gerekmektedir ve bu sadece teknolojinin çok verimli bir şekilde kullanımını ile mümkün olabilmektedir. Bilişim eğitimlerine ağırlık verilmelidir ve herkesin biraz da olsa yazılım dilinden anlaması mümkün kılınmalıdır.

\section{Sonuç ve Öneriler}

Endüstri 4.0'ın oluşum sürecinin tamamlanmamış olmasının yanında, Türkiye henüz Avrupa ülkeleri ile yakın bir seviyeye de gelememiştir. Türkiye'deki şirketler, gelişmiş ülkeler ile karşılaştırıldığında, halen yatırım öncesi ve planlama döneminde olduğu görülmektedir. Bazı görüşler, Türkiye'nin endüstriyel açıdan bulunduğu noktayı 2. Sanayi Devrimi ile 3. Sanayi devrimi arasında bir konumda olarak değerlendirirler. Bunun en önemli sebeplerinden bir tanesi yatırım eksikliğidir. Türkiye'nin Vizyon 2023'te ve AB 2020 Stratejilerinde ortaya konulduğu gibi hedefleri gerçekleştirebilmesi ancak devlet desteği ile birlikte teşvik edilecek yatırımlar ve AR-GE çalışmaları ile mümkün olabilir. Ancak Türkiye'nin farklı gündemi iç ve dış politikasında yaşanan çalkantılı süreçler endüstriyel yatırımların yapılmasına engel teşkil etmektedir.

Endüstri 4.0'ın getireceği yeni iş modelleri ve düzen sebebi ile akıllarda güvenlik, istihdam sorunu gibi endişeler oluşsa da avantajları daha ağır basacak sonuçlar elde edilmesi beklenmektedir. Endüstri 4.0'ın uygulamaya geçirilmesiyle birlikte akıllı robotlar üretim bantlarında yer alacak, bu sayede hata oranı düşerken verimlilik, kalite gibi konularda da işletmeler oldukça büyük adımlar ile ilerliyor olacaklardır. Üretim bantlarının robotlar ile yürütülüyor olması maliyetler dışında, işçi sağlığı ve güvenliği kavramlarında da değişikliklere yol açacaktır. Bu dönüşümleri tamamlayan bir ülkenin üretim maliyetleri, hala geleneksel yöntemlerin hâkim olduğu bir ülkeye göre çok daha düşük seviyelerde olacaktır. Ucuz iş gücü için Doğu'ya kayan üretim yerlerinin merkez ülkelerine dönmesi söz konusu olacağından, Türkiye'nin bu unsuru göz önünde bulundurarak adımlar atması gerekmektedir. Var olan nitelikli iş gücünün korunması da en az nitelikli çalışanların iş gücüne katılması kadar önemlidir. Fason üretim veya alt yüklenici olarak devam edilemeyeceğinin, bu şekilde üretim yapan Türk firmalarca anlaşılması gerekmektedir. Çünkü Endüstri 4.0 geliştikçe Türk fason üreticilerin üretim yaptığı yabancı markaların çok sayıda ve ucuz iş gücüne ihtiyacı kalmayacaktır. Bu nedenle, Türkiye'nin bugün atması gereken en önemli adımlardan biri kendi markalarına sahip olmak ve kendi markalarını üretebilmektir.

Araştırma neticesinde mevcut koşullar göz önünde bulundurulduğunda, Türkiye’nin önünde Endüstri 4.0 için hala kat etmesi gereken uzun bir yol olduğu görülmektedir. Devletin ilgili konularda yaptığı açıklamalara dayanarak, yöneticilerimizin bu hususta hassasiyetlerini ortaya koyduklarını ve bunun umut vaat ettiğini söylenebilir. Bununla beraber en kritik soru, yapılması gereken çalışmaların zamanında ve doğru bir şekilde yapılıp yapılmayacağıdır. Eğitim her şeyin temelidir ve bu alanda çok önemli değişikliklerin yapılması gerektiği herkes tarafindan vurgulanmış olsa da uygulamadaki başarısızlıkların sonuçlarını Türkiye ileride ağır bir şekilde ödeyebilir. Bu nedenle yapılması gereken reformların hızlı ve doğru bir şekilde tamamlanması önem arz etmektedir. Sonuç olarak Endüstri 4.0 için gerekli olan ilk kaynak, robotlardan, internetten, sensörlerden ve her şeyden önce nitelikli insan kaynağıdır. Bu bakımdan gerekli reformların süratli ve düzgün bir şekilde tamamlanması elzemdir. 


\section{KAYNAKÇA}

Akeson, L. (2016), "Industry 4.0 Cyber-Physical Systems and Their Impact on Business Models", Yayınlanmamış Yüksek Lisans Tezi, Karlstads Universitet,Yayınlanmamış Yüksek Lisans Tezi.

Alçın, S. (2016). Üretim İçin Yeni Bir İzlek: Sanayi 4.0. Journal of Life Economics, 3 (2), 19-30. DOI: $10.15637 /$ jlecon. 129

Aslıhan Özüdoğru, A. (2010), “Adana'da Dokuma Sanayi Yapılarının Endüstri Mirası Kapsamında İncelenmesi”, Yüksek Lisans Tezi, Çukurova Üniversitesi Fen Bilimleri Enstitüsü

Brettel, M., Friederichsen, N., Keller, M. ve Rosenberg, M (2014), "How Virtualization, Decentralization and Network Building Change the Manufacturing Landscape: An Industry 4.0 Perspective", World Academy of Science, Engineering and Technology International Journal of Mechanical, Aerospace, Industrial, Mechatronic and Manufacturing Engineering (8): 39

Gürkaynak, M., İren, A. A. (2011), “Reel Dünyada Sanal Açmaz: Siber Alanda Uluslararası İlişkiler”, Süleyman Demirel Üniversitesi İktisadi ve İdari Bilimler Fakültesi Dergisi, 2: 266.

Lee, J., Kao, H. A., ve Yang, S. (2014). Service innovation and smart analytics for industry 4.0 and big data environment. Procedia Cirp, 16, 3-8.

Özdemir, Ş. (2014), "Sanayi Devriminin Bilim Tarihi Üzerine Etkisi”, Üretim Ekonomisi Kongresi Bildirisi.

Özhan, T. (2016), “Makinelerin Evrimi”, eKitap Projesi

Patton, M. Q. (1990). Qualitative evaluation and research methods . SAGE Publications, inc.

Rifkin, J. (2014), “Üçüncü Sanayi Devrimi”, İletişim Yayınları, Birinci Baskı, İstanbul

Taghizadeh, K. (2015), “Sanayi 4.0”, KPMG Yönetim Danışmanlı̆̆ı Araştırma Makalesi.

TUSİAD (2016), “Türkiye’nin Küresel Rekabetçiliği İçin Bir Gereklilik Olarak Sanayi 4.0”, Yayın No: TÜSİAD$\mathrm{T} / 2016-03 / 576$

Üskent, S. B. (2006), “19. YY. İngiliz Romanında Endüstri Devriminin Yansımaları”, Yüksek Lisans Tezi, Ankara Üniversitesi Sosyal Bilimler Enstitüsü

http://blog.kavrakoglu.com/tag/ikinci-sanayi-devrimi/, Nisan 2017.

http://ushistoryscene.com/article/second-industrial-revolution/, Nisan 2017.

http://www.bbc.co.uk/history/historic_figures/watt_james.shtml, Nisan 2017.

http://www.economist.com/node/21552901, Nisan 2017.

http://www.endustri40.com/dunyada-endustri-4-0/, Haziran 2017

http://www.endustri40.com/endustri-tarihine-kisa-bir-yolculuk/, Haziran 2017.

http://www.endustri40.com/siber-fiziksel-sistemler/, Nisan 2017

http://www.endustri40.com/turkiyede-endustri-4-0/, Haziran 2017.

http://www.gazeteekonomi.com/ekonomi/sanayi-40-konferansinda-engelse-gonderme-h153237.html， ， Nisan 2017.

http://www.mckinsey.com/business-functions/operations/our-insights/how-big-data-can-improve-manufacturing, Nisan 2017.

http://www.otomasyondergisi.com.tr/arsiv/yazi/97-turkiyenin-kuresel-rekabetciligi-icin-bir-gereklilik-olaraksanayi-40, Nisan 2017.

http://www.pwc.com/gx/en/industries/industry-4.0.html, Haziran 2017. 
http://www.tarihiolaylar.com/tarihi-olaylar/sanayi-devrimi-1107, Nisan 2017.

https://hbrturkiye.com/endustri-4-0-akilli-fabrikalarin-akilli-guvenligi, Nisan 2017.

https://industryolog.com/dijital-sanayi-devrimi-4-endustri-4-0da-3d-yazicilar/, Mayıs 2017.

https://tr.wikipedia.org/wiki/B\%C3\%BCy\%C3\%BCk_veri, Nisan 2017.

https://tr.wikipedia.org/wiki/Bulut_bilişim, Nisan 2017.

https://www.bcg.com/publications/2015/engineered_products_project_business_industry_4_future_productivity _growth_manufacturing_industries.aspx, Mayis 2017.

https://www.muhendisbeyinler.net/4-sanayi-devrimi-nedir/, Nisan 2017. 